\title{
Threats and opportunities for post-closure development in dolomitic gold mining areas of the West Rand and Far West Rand (South Africa) - a hydraulic view Part 1: Mining legacy and future threats
}

\author{
Frank Winde* and EJ Stoch \\ North-West University, Potchefstroom Campus, Private Bag X6001, Potchefstroo, 2520, South Africa
}

\begin{abstract}
For long periods in the history of South Africa gold mining formed the backbone of an otherwise agriculturally-dominated economy, initiating rapid urbanisation in often remote and underdeveloped farming areas. This paper explores examples from a mined-out goldfield west of Johannesburg (West Rand), where consequences of mine closure can currently be observed, as well as from an active goldfield on the Far West Rand. Both areas are linked by the Wonderfonteinspruit, a stream drawing much national and international media attention for its high levels of radioactive pollution. Dating back more than 120 years, the impacts of gold mining and later uranium mining on the natural environment are profound and complex, perhaps most affecting the rich groundwater resources found in the exceptionally well-karstified dolomite that underlies most of the catchment area. Mining-related impacts such as large-scale land degradation associated with dewatering of karstic aquifers and widespread pollution of surface water and groundwater systems are discussed. Based on this, potential threats and opportunities for post-mining scenarios are identified in a series of 3 papers. Part 1 of this series outlines impacts of mining, particularly on the natural water resources, and possible consequences associated with the future re-watering of currently de-watered dolomitic compartments. The need for a regionally-integrated approach to the closure of highly interconnected mines is stressed and timelines of the closure process estimated. In Part 2 the emphasis is on identifying possible opportunities for post-mining development centred mainly around the utilisation of exceptional karst features and associated water resources. Part 3 aims to quantify uncertainties associated with planning in miningdominated environments by comparing historical predictions with factual developments.
\end{abstract}

Keywords: gold mining, West Rand, Far West Rand, dolomite, karst, dewatering, water pollution, tailings, uranium, mine closure, re-watering

\section{Introduction}

Gold-mining activities in the Wonderfonteinspruit (WFS) area of South Africa date back more than 120 years, initiating rapid urbanisation which turned largely rural and underdeveloped areas into densely-populated regions boasting $1^{\text {st }}$ class infrastructure which includes roads, railway lines, water and electricity systems, schools, hospitals, supermarkets, etc. Many towns, such as Randfontein, Westonaria and Carletonville, owe their very existence to gold mining, and gold mines are still the most important source of direct or indirect income, raising concerns about implications of (inevitable) mine closure in the future. There are fears of socio-economic breakdown based on well-known 'ghost town' scenarios in other mining regions. This is exacerbated by a legacy of environmental degradation caused by century-old mining. Much of the degradation has been caused by large-scale dewatering of some of South Africa's most important aquifers, resulting in the widespread and devastating occurrence of sinkholes and dolines. In addition, water, sediments and soils have been contaminated with radioactive uranium (Winde, 2006a).

Presented in 3 parts, this paper aims to analyse impacts of mining on natural resources in order to assess the potential resulting threats to post-mining developments (Part 1). Based

\footnotetext{
* To whom all correspondence should be addressed.

푤 +2718 299 1582; fax: +2718 299 1582;

e-mail: frank.winde@nwu.ac.za

Received 5 August 2009; accepted in revised form 9 December 2009.
}

on this analysis, Part 2 outlines opportunities for post-mining development, centring largely on the utilisation of the abundant dolomitic water resources in the area. In the last part of the series (Part 3), predictions of historical planning documents are compared to actual developments subsequently observed in the area in order to illustrate the degree of uncertainty often associated with planning in mining-dominated environments.

\section{Gold mining in the study area: Historical development and environmental impacts}

\section{The West Rand goldfield}

Soon after the discovery of gold in 1886 , on a farm in the middle of the semi-arid interior plateau known as the 'Highveld', rapid urbanisation led to the development of Johannesburg, today one of the largest metropolitan areas in Africa. Aided by capital from the diamond fields in Kimberley, gold mining rapidly expanded along the outcropping gold ore ('reef') to the east and west of the site of discovery, later known as the 'Central Rand'. The term 'Rand' is derived from the Afrikaans 'Witwatersrand' ('ridge of white waters'), used to describe an outcrop of exceptionally hard layers of sedimentary rock, lending its name not only to the world's largest-known gold deposit (the Witwatersrand Basin) but also to the currency of South Africa, indicating the economic significance of gold mining for the country. In 1887, only 1 year later, gold mining had moved $30 \mathrm{~km}$ west of Johannesburg, with 'West Rand Consolidated' the $1^{\text {st }}$ mining company to operate in a newly-established 


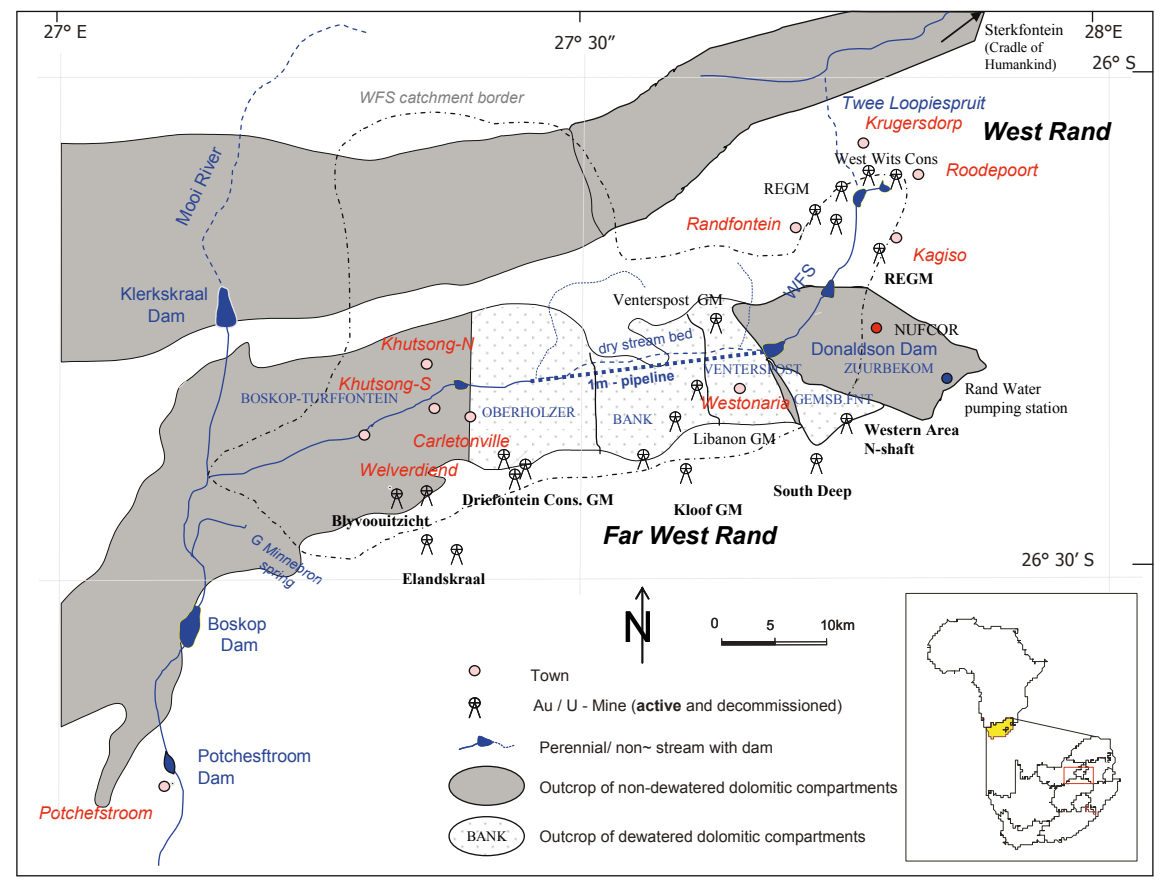

Figure 1

Study area goldfield known as 'West Rand' (WR). In April of the same year the Transvaal Government established the town of Krugersdorp (named after then President Paul Kruger) to serve as administrative centre for the public gold diggings proclaimed in the area (Erasmus, 2004; Robb and Robb, 1998; Marais, 2000) (Fig. 1)

In 1890, (Sir) JB Robinson, a successful diamond magnate from Kimberley, established the Randfontein Estates Gold Mine (REGM) together with the town of Randfontein ('spring on the ridge') to accommodate the large workforce needed for the increasingly labour-intensive underground mining (Anderson et al., 1986; Robb and Robb, 1998; Erasmus, 2004). Migrant workers from China were brought to South Africa in order to combat the shortage of skilled underground labourers soon felt by the rapidly expanding mines. One of the first shafts in which highly-polluted water from the flooded mine void surfaced some 100 years later, and which could not be found on any plan (today referred to as the 'Black Reef Incline Shaft'), is believed to have originated from the efforts of these early Chinese miners.

Continuing to rely on imported (migrant) labour, gold mines later preferred to recruit workers from countries geographically closer to South Africa, such as Lesotho (from where, apparently, the best shaft sinkers come), Mozambique, Botswana and others, often through formalised bilateral agreements at Governmental level (Wiehahn, 1982). While the overwhelming majority of contracted migrant workers were housed in large, dedicated single-sex hostels located on-site, other, mainly Black, job-seeking migrants flocking to the area had to settle outside 'White' mining towns in so-called 'townships' and 'locations' or informal settlements (Mohlakeng, Toekomsrus, Bekkersdal and others). Today, urban growth encroaches ever closer onto abandoned (and often contaminated) mine property. In some instances shacks have been built directly onto old slimes dams exposing inhabitants to a range of potential health risks including radon exhalation, radiation, dust and other tailings-related hazards.

As the last operational mine on the West Rand, REGM ceased active underground mining in the 1990s. From then on a system of interlinked voids, collectively known as 'Western Basin' and created by 4 different mines over more than a century, started to fill up with naturally inflowing water. This water finally reached the surface in 2002, displaying extremely poor quality mainly due to underground chemical processes known as 'acid mine drainage' (Fourie and Associates, 2004). Amongst other constituents, the radioactive heavy metal uranium, which accompanies gold in the mined reefs, was elevated to such an extent that the National Nuclear Regulator (NNR) of South Africa declared the site at which the water surfaced ('decant site') an access-restricted 'radiation area'.

Although much of the mine void expands below the headwater area of the WFS, which drains towards the Atlantic Ocean, most of the mine-water crosses below the sub-continental divide decanting into a small (normally non-perennial) stream known as Twee Lopiespruit East ('Two course stream' East) which finally drains into the Indian Ocean. With an estimated $15-30 \mathrm{M} \ell / \mathrm{d}$ (rising up to $50 \mathrm{M} \ell / \mathrm{d}$ during wet periods) of highly polluted water running through the Krugersdorp Game Reserve, located a short distance below the decant point, and further towards the Sterkfontein Caves, concerns have been raised about health implications for animals in the Game Reserve (Du Toit, 2006) and also Sterkfontein's ('strong fountain') UNESCO World Heritage status as the 'Cradle of Humankind' (Fourie and Associates, 2004). Du Toit (2006) reports the death of 27 animals (9 lions and 18 springbuck) in the Game Reserve within months of the decant, although no clear cause-effect relationship between mine-water and animal deaths could be established, partly due to a lack of scientific data for wild (i.e. non-domestic) animals.

After it was initially considered to supply this water to platinum mines in the north where water scarcity had already curbed production, a later-issued DWAF directive urged the responsible mine (Harmony Gold Mine (GM)) to capture the decant water and, after reducing uranium, iron and sulphate levels, to divert it into the WFS. Interestingly, the facility currently used by the mine for the water treatment and uraniumremoval (now operated by Rand Uranium) is built on the remains of a former uranium-production plant. 
Companies such as Mogale Gold have been extracting gold from old tailings dams and sand dumps intermittently, but since 2003 a sharp increase in the price of uranium has sparked renewed interest in large-scale reworking of uraniferous tailings deposits (in South Africa termed 'slimes dams'). This has transformed many of the old slimes dams, formerly an environmental liability to their owners, into economic assets, many of which are now exploited by joint-venture companies specifically established for this purpose (Hill, $2008 \mathrm{a}$; b). This continues a history which started in 1952 when the $1^{\text {st }}$ fully-operational uranium plant in South Africa was commissioned at the West Rand Consolidated Gold Mine (Erasmus, 2004) (Fig. 1).

\section{The Far West Rand goldfield}

Attempts to mine gold south of the WR (e.g. by the Pullinger brothers in 1911) failed initially as large volumes of water from dolomitic karst aquifers flooded the newly-sunken shafts. It was only in 1934 that the recently-developed cementation technology allowed the Venterspost Gold Mine to sink shafts successfully through water-bearing dolomite, tapping into the riches of a new goldfield known today as Far West Rand (FWR) (Fig. 1). This was soon followed by other mines established down the catchment of the WFS. The newly-discovered gold reefs proved to be the richest mined in South Africa. Gold mines (GMs) such as Blyvooruitzicht and later West-Driefontein were, in their heyday, the world's richest gold mines (GFL, 2005).

West Driefontein GM applied to government for permission to dewater overlying dolomitic compartments in an effort to reduce the ever-increasing pumping costs that many mines incurred in more than $3 \mathrm{~km}$-deep mine workings. After a 4-yr inter-departmental investigation, in 1964 the Government finally granted permission to GMs to dewater 2 dolomitic compartments, which de facto had already commenced years before (Jordaan et al., 1960). Starting with the Venterspost (1947) and Oberholzer (1959) compartments, dewatering was later extended to the Bank (1969) and Gemsbokfontein (1986) compartments. In order to provide a legal framework for compartment dewatering, the Irrigation and Water Conservation Act (No. 8 of 1912) was replaced by the Water Act (No. 54 of 1956). This was the $2^{\text {nd }}$ time that water issues in the WFS catchment had set a precedent for water law in South Africa, as Chapter 3 of the Irrigation and Water Conservation Act was amended to replace the authority of the Governor-General and increase the Minister of Water Affairs' power over dolomitic water (Swart et al., 2003a).

By pumping out more water from the underlying mine void than was naturally replenished in the dolomite, and discharging the pumped water downstream of the affected compartments, the groundwater level was lowered by up to $1000 \mathrm{~m}$ in places. Apart from the (anticipated) drying up of irrigation boreholes and some of the strongest karst springs in South Africa, which historically fed into the WFS dewatering also (unexpectedly) caused a massive acceleration of karst-related ground instability in the form of sinkholes and dolines, frequently with dire consequences for residents and local infrastructure. The most catastrophic sinkhole on record occurred in 1962 at WestDriefontein GM, where the 7-storey-high screening, crusher and sorting plant disappeared completely, trapping 29 workers, none of whom could be rescued, followed by a sinkhole in 1964 at Blyvooruitzicht village killing a family of 5 (GFL, 2005). In order to compensate affected farmers and other parties for the loss of land, Government and the Chamber of Mines reached an Agreement to form the Far West Rand Dolomitic Water Association (FWRDWA), of which it is itself a member, represented by 2 officials from the Department of Minerals and Energy (DME, recently renamed as the Department of Mineral Resources) and 1 official from the Department of Water Affairs and Forestry (DWAF, which was recently reconstituted as 2 Departments headed by 1 Minister, namely, the Department of Water Affairs (DWA) and Department of Environmental Affairs; in this paper the acronym 'DWA' will be used to refer to what was formerly the DWAF). The FWRDWA was expected to speedily resolve dewatering-related claims, including the provision of alternative water. As part of the planned dewatering of the Bank Compartment, the very settlement after which the Compartment was named ('Bank') was evacuated and subsequently dismantled. Today, most of the dolomitic land overlying the affected compartments on both sides of the WFS is owned by the FWRDWA, of which Government is an indirect two-thirds shareholder.

Over the past 50 years or so, well over 1000 sinkholes have formed in the area, many of them directly in the streambed of the WFS, where karstification naturally is most intense (Swart et al., 2003a). By intercepting much of the streamflow and diverting it to the underlying mine void, sinkholes in the streambed drastically increased pumping costs for affected mines. Triggered by an exceptionally wet period between 1974 and 1978, in 1977 the WFS was diverted into a $32 \mathrm{~km}$-long pipeline of $1 \mathrm{~m}$ diameter (commonly referred to as ' $1 \mathrm{~m}$-pipeline') carrying water across the 3 dewatered compartments. Government at the time paid approximately two-thirds of the construction cost amounting to a total of USD $5 \mathrm{~m}$. With a maximum capacity of some $130 \mathrm{M} / \mathrm{d}$, the pipeline can, however, not accommodate all runoff generated in the relatively steep, non-dolomitic head-water region of the WFS, especially after intensive storm events. During the said wet period in the mid-1970s, up to $3500 \mathrm{M} \ell / \mathrm{d}$ overflowed from Donaldson Dam (Fig. 1) towards the pipeline, resulting in more than $96 \%$ of the runoff bypassing the pipeline and entering the streambed at a section where, since 1954, a total of 166 sinkholes had formed. Accepting up to $40000 \mathrm{l} / \mathrm{s}$, sinkholes in the streambed diverted the entire runoff into the underlying mine void causing groundwater levels to rise to as close as $10 \mathrm{~m}$ below the streambed, almost reaching pre-dewatering levels again. The concentrated water input during this wet period caused an increase in pumping volumes of affected mines for a further 12 years before normal pumping levels were again reached (Swart et al., 2003b).

In order to reduce the significant volume of stormwater that runs into sinkholes, several attempts were made to fill sinkholes with a mixture of waste rock and tailings material. After further deterioration of the streambed, Gold Fields of South Africa in the 1990s filled 271 sinkholes occurring within $100 \mathrm{~m}$ of each side of the WFS streambed with a total of $2.45 \cdot 10^{6} \mathrm{~m}^{3}$ of material (Swart et al., 2003b). Some sinkholes accepted the daily tailings production from nearby metallurgical plants for several months before they were finally filled. In a number of instances, however, the tailings suddenly disappeared overnight into underlying karst receptacles (Swart et al., 2003b). Similar problems were encountered at numerous slimes dams often placed directly onto cavernous dolomite to facilitate drainage of pore-water and support dam stability. This, in turn, resulted in significant volumes of tailings seepage, accelerating subsurface erosion of fine material in karst cavities and subsequently causing the formation of sinkholes in several slimes dams (SD). At one particular slimes dam (No. 3 of Doornfontein GM), a total of 52 sinkholes occurred over a period of 12 years, releasing large amounts of uraniferous material directly into the underlying aquifer. Where affected SDs are located 
in dewatered compartments, operating gold mines are likely to 'suck in' possible seepage together with pumped dolomitic groundwater. In some instances, however, sinkhole-ridden SDs are located in the full (i.e. not-dewatered) Boskop-Turffontein Compartment at the lower end of the catchment, which currently provides a large proportion of the drinking water of downstream communities such as Potchefstroom. Continuously deteriorating water quality over the past 35 or so years, as observed in a downstream karst spring (Gerhard Minnebron Eye), may well be an indicator of long-term groundwater pollution caused by upstream gold mining (DWAF, 2005).

Apart from groundwater, uranium is also found, and often in much higher concentrations, in surface water bodies, including the WFS. Owing to a range of chemical and physical processes which remove dissolved uranium from the water phase, contamination is not confined to water but also affects fluvial sediments in dams, wetlands and floodplains (Winde, $2006 \mathrm{~b}$; c). Following the recent publication of studies indicating the possibility of radioactive pollution causing adverse health effects in local residents as well as downstream water users (Wade et al., 2006; Winde, 2006d; Barthel, 2007), the WFS currently receives extensive media coverage at local, national and even international levels. In response to mounting pressure from NGO's and members of the public, government has currently given an undertaking to address these risks and remediate pollution where necessary (DWAF, 2007).

Through successive consolidation, most mines in the study area are now part of one of the 4 major mining houses operating in South Africa, namely, Gold Fields Limited (GFL), Harmony Gold, AngloGold Ashanti and Durban Roodepoort Deep (DRD). An exception to this is the former No. 4 shaft of Harmony (previously N-shaft of Western Areas), which is now operated by Simmer \& Jack as a uranium mine ('Ezulwini') (Hill, 2007) after previous plans to rewater this part of the Gemsbokfontein Compartment (which links the area to the WFS) were abandoned.

In many cases consolidation may have buffered possible effects of closure of smaller mines, through retaining staff and using existing infrastructure to supplement adjacent operating mines with services such as pumping, ventilation, hoisting, etc., as illustrated at the former Ventersdorp and Libanon GMs which now form part of Kloof Division (GFL). A most recent example is the South Deep GM (formerly Western Areas - South Mine) which was acquired by GFL with the intention of accessing the world's largest-known, single gold reserve through existing infrastructure of the adjacent Kloof Mine.By joining underground workings of different gold mines, vast interlinked mine voids are created, which, as recently proven by the Western Basin, will be difficult to model once mining has ceased and data have been lost. Creating up-to-date databases is further complicated by frequent changes in ownership, names and staff of mines and the accompanying loss of site-specific expertise, especially where the periods run over several decades. With such 'loss of institutional memory' afflicting mining companies and governmental regulators alike, it is particularly challenging to retain sufficient data, information, knowledge and expertise for reliably predicting post-closure scenarios.

\section{Mine closure}

Experiences from other goldfields suggest that mine closure will most probably be a gradual process, that can stretch over decades, during which mines cease operation at different points in time, according to their profitability. During this extended period influxes of water from abandoned voids into operational mines proved to be a major threat to the profitability of affected mines, as examples from the East Rand (ERPM) and the Klerksdorp goldfields (AngloGold Ashanti) illustrate. Future plans for post-mining development must therefore take into account the implications of interconnected mine voids, by approaching mine closure proactively in a regionally-integrated fashion.

Owing to the increased costs of mining ever-deeper gold reefs, the output of South African gold mines has continued to decline since 1970 but is still sufficient to make South Africa the $3^{\text {rd }}$ largest producer of gold in the world, surpassed only by China (which overtook South Africa in 2007) and Canada (Robb and Robb, 1998; Campell, 2004; West, 2009). Fuelled by rising demand for mineral resources from rapidly industrialising countries such as China and India, prospects are good that mining in South Africa will continue to be a significant foundation industry for decades to come (Campell, 2004). In the case of gold this is underpinned by a historically unique situation in which an all-time price high is accompanied not by a strengthened Rand (ZAR), as is commonly the case for currencies of mining-dependent economies (thus reducing the USD -based revenue for South African gold mines), but by a local currency which continues to weaken. This combination of exceptionally high gold-prices and a comparably weak ZAR resulted in record ZAR gold prices of ZAR320 000/kg in February 2009 almost 4 times higher than it was in 2004. However, significant increases of production costs to a current average of approximately ZAR251 000/kg limited the net profit (West, 2009). Using current technology, South African gold mines can still access $15000 \mathrm{t}$ of gold with another $20000 \mathrm{t}$ available at depths greater than $3 \mathrm{~km}$, for which a new (ultra-deep) mining technology is required (Campell, 2004). As a result lifespans of gold mines in the Far West Rand have significantly been extended, in some cases by up to several decades. With accompanying deepening projects it is envisaged that at the end of mining in the FWR goldfield, the world's 3 deepest mines will be located here (Mponeng, AngloGold Ashanti: 4300 m; Driefontein, GFL: $4121 \mathrm{~m}$ and Kloof, GFL: 4020 m; (Venter, 2007; Creamer, 2008)). While gold output and number of employees may continue to decline, mine closure in the FWR is still 2 generations away. An indication of the healthy state of gold mining is, for example, the operating profit of GF,L as a major mining house in the area, which rose from ZAR2.3 bn. in 2005 to ZAR4.4 bn. in 2006 (Brown, 2006), and that was well before the gold price approached the current record highs in late 2007. Renewed interest in uranium, following sharp rises for the radioactive metal since 2003, may also revive the uranium mining for which the area was known. With the re-opening of the former Western Areas North shaft to mine uranium, as well as plans for large-scale uranium extraction from tailings of almost all mining houses in the area, not only gold- but also uranium mining is set to continue in the WFS area for many years to come (Hill, $2008 \mathrm{a} ; \mathrm{b})$.

\section{Mining-related urbanisation}

Before assessing the implications for urban development of closing gold mines, the extent of mining-related urbanisation is briefly outlined. Settlements initiated or associated with gold mining in the FWR area include: Carletonville (established 1948, named after Guy Carleton Jones, the Canadian-born chief engineer of Gold Fields of South Africa), Blyvooruitzicht villages (associated with the mine of the same name which started active mining in 1943), West- and East-Driefontein villages 
(associated mines were commissioned in 1952 and 1972 respectively), the Deelkraal and Elandsrand villages (both mines of the same name later amalgamated to the Elandskraal GM), the Venterpos settlement (est. 1935), the Libanon village (est. 1936, now part of Kloof GM), as well as Westonaria (est. 1959, originally linked to Western Areas GM). At the time of establishment of many of the towns, apartheid policy forced Black job seekers and workers not living on mine property to settle in townships such as Bekkersdal (associated with Westonaria), Khutsong (associated with Carletonville) and several smaller 'locations' next to 'White' mining towns. Currently an estimated total of 600000 people live in the area, of which approximately $50 \%$ stay in previously 'Black' townships that still suffer from substandard infrastructure including water and sanitation systems (DWAF, 2004). In view of the fact that a census for Khutsong alone established a population of 180000 (compared to a figure of 68000 reported by DWAF (2004)), this population estimate is most likely too low. With an estimated population growth of $10 \%$ per year, further extensions of current settlements are to be expected (Spies, 2007). Since limited access to resources generally increases the need for (cheap) alternatives, inhabitants of townships are commonly more likely to use polluted media (water, soil, tailings), even in cases where they are aware of potential dangers or where this is illegal. This, again, increases exposure to pollutants in the very population which is most vulnerable owing to inadequate medical and health care, malnutrition, poverty and related stress such as drug abuse as well as effects of other environmental stressors including indoor air and dust pollution.

\section{Mining legacy and resulting future threats}

Many of the towns and, to a lesser extent, the townships benefited from mining-related infrastructure, such as hospitals, schools, sport facilities, and $1^{\text {st }}$ class infrastructure including 4-lane highways, well-maintained reticulation systems for water and electricity and a range of recreational sites such as dams and golf courses, etc. With almost the entire economy in towns such as Carletonville or Westonaria somehow dependent on the mines, ranging from suppliers, craftsmen and consultants to supermarkets, cafés and hairdressers, the (inevitable) closure of mines is perceived as a fundamental threat to the economic future of these municipalities. Adding to the bleakness of such prospects of economic collapse and unemployment is often a mining legacy of environmental degradation and social problems such as increased HIV infection rates and xenophobia, both linked to the migrant labour system employed by mines for decades (Turton, 2008). Combined with slow or lacking progress in service delivery, this has already fuelled social unrest and riots in Khutsong, a township mostly populated by foreign migrant workers who did not return to their home country. It is therefore conceivable that bleak future prospects are, indeed, a real threat, not only to the economy but also to the social fabric and political stability of mining-dependent communities in the entire area.

The near-hysteria evoked by the recent media attention to mining-related pollution of the WFS may well be a subconscious indicator and a means for the venting of such fears. This could be especially true for the WR, where former benefits from mining in the form of employment and income are fading, while environmental degradation becomes more apparent by the day. Ad hoc interviews of residents in Carletonville, where mining still exists, about their perception of mining-related risks such as sinkholes and water pollution, revealed that the overwhelming majority preferred to either ignore such risks or discount them for benefits derived from the mines (NWU, 2006).

Judging by the dire consequences that the uncontrolled rewatering in the WR has had on the environment, it is of utmost importance that effects associated with the flooding of the much larger mine void in the FWR, and subsequent re-watering of dewatered dolomitic compartments, are well understood before they are allowed to happen. Aspects of particular concern include:

- A period of severely-reduced water availability during the re-watering phase when no water will be pumped by mines into the Wonderfonteinspruit

- The question of whether or not dried-up karst springs will flow, thus making irrigation possible again

- Where potential decant points will be located and what the water quality of the decanting water will be

- Whether ground stability will be affected by recovering water tables possibly leading to the activation of old, and/or formation of new, sinkholes.

The fact that more than 10000 households are currently earmarked for relocation from Khutsong North, where a number of sinkholes have formed over many years, to another (also dolomitic) area further south illustrates the magnitude of this aspect (U\&E Development Economists, 2005).

Owing to the interconnectivity of the different mine voids in the FWR, similar problems to the ones recently encountered in dolomitic parts of the East Rand and Klerksdorp goldfields, as mentioned earlier, are to be expected. Owing to difficulties in apportioning water volumes to different voids, it is often problematic to find amicable solutions for sharing pumping costs, especially for non-revenue generating mines (Winde et al., 2006).

In growing recognition of the degree to which different mines are impacting on each other, governmental authorities such as the DWA and the Department of Mineral Resources increasingly demand regionally-integrated approaches from different gold mines applying for water use licences and closure certificates, respectively (Van der Merwe, 2008).

\section{Conclusions}

Over more than a century of deep-level gold mining the WFS catchment has been profoundly impacted both positively as well as negatively. While providing $1^{\text {st }}$ class infrastructure and income to a large number of people in a previously underdeveloped area, mining also adversely affected natural resources through large-scale land degradation as an unforeseen side effect of dewatering karstic aquifers as well as through longterm pollution of the environment. In view of the adverse impacts of uncontrolled re-watering currently experienced in the mined-out WR goldfield, it is of utmost importance that comparable impacts are avoided in the FWR, where a much larger interconnected mine void and higher volumes of potentially decanting mine-water could have even more catastrophic effects. To this end it is recommended that data, expertise and information needed for reliably modelling and predicting the effects of future re-watering are secured, for as long as the mines hosting most of this information are still operational. In developing concepts related to mine closure it is necessary to adopt an integrated regional approach taking into account accumulating and combined effects of individual mines on 
natural resources such as surface water and groundwater, as well as impacts on each other. Overcoming potentially devastating effects of mine closure should be the first and most important step in securing sustainable post-mining development. Opportunities for the latter are discussed in Part 2 of this paper (Winde and Stoch, 2008).

\section{References}

ANDERSON, WILSON \& PARTNERS INC. (1986) West Witwatersrand Goldmines, Sheet 1: Map 1:125 000 (cartography: Strickler PJ): Mine lease areas and holding companies as per 30 September 1985.

BARTHEL R (2007) Assessment of the Radiological Impact of the Mine Water Discharges to Members of the Public Living around Wonderfonteinspruit Catchment Area. BSA-Project-No. 0607-03, BS Associates, Consulting Engineers and Scientists. Report to the National Nuclear Regulator (NNR), Contract No. RRD/RP01/2006, Bedfordview. (unpublished). $225 \mathrm{pp}$.

BROWN J (2006) Safety at Gold Fields collapses as profit soars. The Star (4 August).

CAMPELL K (2004) Future of mining in SA. Mining Weekly online, 28 May 2008. URL: www.miningweekly.com (Accessed 28 May 2008). 5 pp.

CREAMER M (2008) AngloGold's Mponeng will be world's deepest mine from Sept, new R9bn project to go to board Oct. Mining Weekly online, 22 May 2008. URL: www.miningweekly.com (Accessed 23 May 2008). 2 pp.

DU TOIT S (2006) Practical applications - Effects of mine water drainage on the Krugersdorp Game Reserve. Proc. Conf. on Mine Water Decant. 14-15 October 2006, Randfontein, South Africa. Mine Water Division, Water Institute of South Africa. 8 pp.

DWAF (DEPARTMENT OF WATER AFFAIRS AND FORESTRY, SOUTH AFRICA) (2004) Database on Sanitation and Water Access in Communities of SA (unpublished).

DWAF (DEPARTMENT OF WATER AFFAIRS AND FORESTRY, SOUTH AFRICA) (2005) Water Quality Data for Station C2H011, Gerhard Minnebron Eye, 1965 to 2000.

DWAF (DEPARTMENT OF WATER AFFAIRS AND FORESTRY, SOUTH AFRICA) (2007) Wonderfonteinspruit Catchment Area Radiological Contamination Mitigation Plan, Terms of Reference (unpublished). $4 \mathrm{pp}$.

ERASMUS BPJ (2004) On Route in South Africa - A Region by Region Guide. Jonathan Ball Publishers, Cape Town, South Africa. 336-338.

FOURIE AND ASSOCIATES (2004) The Potential Effects of Acid Mine Drainage on the Dolomites in the Crocodile River Catchment Area with Specific Reference to the Sterkfontein Sub-Compartment of the Swartkranz Dolomitic Formation and the Cradle of Humankind. Report to DWAF by HJ Fourie and Associates Environment Engineers on behalf of Harmony Gold Mine (unpublished). $34 \mathrm{pp}$.

GFL (GOLD FIELDS LTD) (2005) Salute this special mine. Ngonyama News 27 (October 2005).

HILL M (2007) First Uranium studies second Ezulwini shaft. Mining Weekly online, 27 July 2007. URL: www.miningweekly.com (Accessed 27 July 2007). $1 \mathrm{p}$

HILL M (2008a) Harmony could start uranium production in 2010. Mining Weekly online, 22 May 2008. URL: www.miningweekly. com (Accessed 22 May 2008). 2 pp.

HILL M (2008b) Gold Fields looking to develop West Wits surface assets. Mining Weekly online, 9 May 2008. URL: www.miningweekly.com (Accessed 10 May 2008). 2 pp.

JORDAAN JM, ENSLIN JF, KRIEL J, HAVEMANN A, KENT LE and CABLE WH (1960) (11/1960) Final report of the Interdepartmental Committee on Dolomitic Mine Water: FWR to Minister of Water Affairs by the Director of Water Affairs (unpublished). Pretoria. $38 \mathrm{pp}$.
MARAIS M (2000) Status Report on Dust Pollution at Durban Roodepoort Deep Ltd Central and West Rand. Durban Roodepoort Deep Report No. DRD DPD 001, 29 October 2000, (unpublished).

NWU (NORTH-WEST UNIVERSITY) (2006) Wonderfonteinspruit excursion: Day 2 - social issues in Merafong, interview with local residents. Excursion report of $3^{\text {rd }}$ year Geography students (unpublished). $23 \mathrm{pp}$.

ROBB LJ and ROBB VM (1998) Gold in the Witwatersrand Basin. In: Wilson MG and Anhaeusser CR (eds.) The Mineral Resources of South Africa. Handbook, Council for Geoscience 16 294-349.

SPIES C (2007) Personal communication, 4 April 2007. Communication Officer, Merafong City Council, Merafong (formerly Carletonville)

SWART CJU, STOCH EJ, VAN JAARSVELD CF and BRINK ABA (2003a) The Lower Wonderfontein Spruit: an exposé. Environ. Geol. 43 635-653.

SWART CJU, JAMES AR, KLEYWEGT RJ and STOCH EJ (2003b) The future of the dolomitic springs after mine closure on the Far West Rand, Gauteng, RSA. Environ. Geol. 44 751-770.

TURTON AR (2008) Water and mine closure in South Africa: development that is sustainable? On-line Dialogue 2008: Water and Development. URL: www.sidint.org/development (Accessed 15 June 2008). 11 pp.

U\&E DEVELOPMENT ECONOMISTS (2005) Local Economic Regeneration Study. Merafong Municipality (unpublished).

VAN DER MERWE C (2008) SA studies regional mine closure strategy. Mining Weekly online, 27 May 2008. URL: www.miningweekly.com (Accessed 17 June 2008). 2 pp.

VENTER I (2007) Miners dig to record depths to find more gold. Mining Weekly online, 1 June 2007. URL: www.miningweekly.com (Accessed 17 June 2007). 6 pp.

WADE P, WINDE F and COETZEE H (2006) Risk Assessment. In: Coetzee H, Winde F and Wade P (eds.) An assessment of sources, pathways, mechanisms and risks of current and potential future pollution of water and sediments in gold mining areas of the Wonderfonteinspruit catchment (Gauteng/ North West Province, South Africa). WRC Report No. 1214/1/06. Water Research Commission, Pretoria, South Africa.

WEST E (2009) SA third-quarter gold output lags in boom. Business Day, 18 November 2009. URL: http://www.businessday.co.za/articles/Content.aspx?id=87395 (Accessed 18 November 2009).

WIEHAHN NI (1982) The Complete Wiehahn Report ( $1^{\text {st }}$ edn). Lex Patria Publishers, Johannesburg, Cape Town.

WINDE F (2006a) Impacts of gold and uranium mining on water resources in dolomitic karst areas in South Africa - examples from the Wonderfonteinspruit catchment. Geo-Öko 27 (1-2/2006) 52-76.

WINDE F (2006b) Challenges for sustainable water use in dolomitic mining regions of South Africa - a case study of uranium pollution, Part I: sources and pathways. Phys. Geogr. 27 (2) 335-346.

WINDE F (2006c) Challenges for sustainable water use in dolomitic mining regions of South Africa - a case study of uranium pollution, Part II: Spatial patterns, mechanisms and dynamics. Phys. Geogr. 27 (2) 379-395.

WINDE F (2006d) Impacts of gold-mining activities on water availability and quality in the Wonderfonteinspruit catchment. In: Coetzee H, Winde F and Wade P (eds.) An assessment of sources, pathways, mechanisms and risks of current and potential future pollution of water and sediments in gold mining areas of the Wonderfonteinspruit catchment (Gauteng/ North West Province, South Africa). WRC Report No. 1214/1/06. Water Research Commission, Pretoria, South Africp. 13-34.

WINDE F, STOCH EJ and ERASMUS E (2006) Identification and quantification of water ingress into mine voids of the West Rand and Far West Rand goldfields (Witwatersrand basin) with a view to long-term sustainable reduction thereof. Final report to the Council for Geoscience, Project No. 5512 (unpublished). 261 pp.

WINDE F and STOCH EJ (2010b) Threats and opportunities for postclosure development in dolomitic gold mining areas of the West Rand and Far West Rand (South Africa) - an hydraulic view. Part 2: Opportunities. Water SA 36 (1) 75-82. 